\title{
PENGARUH SERTIFIKASI GURU TERHADAP KETERAMPILAN MENGAJAR DIKELAS PADA SEKOLAH DASAR SE-KECAMATAN SUNGAI RAYA KABUPATEN BENGKAYANG
}

\author{
Ressi Nata Sumanda ${ }^{1}$, Yulita Pujiharti ${ }^{2}$ \\ 1Pendidikan Ekonomi, IKIP Budi Utomo \\ e-mail: ressinata92@gmail.com \\ 2Pendidikan Ekonomi, IKIP Budi Utomo \\ e-mail: yulitapujiharti@budiutomomalang.ac.id
}

\begin{abstract}
The teacher as a professional job with the passing of law No. 14 of 2005 concerning teachers and lecturers on December 15, 2005. According to the Act, teachers are professional educators with the main task of educating, teaching, guiding, directing, training, evaluating, and evaluating students in early childhood education through formal education, basic education and secondary education. The study was conducted to determine the effect of teacher certification in implementing teaching skills in the classroom at elementary schools in Sungai Raya sub-district. This is due to the limited tools, media and learning materials in elementary schools in Sungai Raya sub-district. The object of this study is elementary school teachers who have been certified or who have not been certified in the Sungai Raya sub-district of Bengkayang Regency. The purpose of this study is (1) to determine the implementation of teaching skills of certified teachers in class, (2) to find out the implementation of teaching skills of teachers not certified in class, (3) to find out whether there is an influence of teacher certification on the implementation of teaching skills of teachers in class - Sungai Raya subdistrict of Bengkayang Regency. Researchers use this type of comparative quantitative research. The results of the research that have been carried out in the field can be concluded as (1) Certified teachers in implementing teaching skills are on the skilled criteria with an average of 76.79562. (2) Teachers who have not been certified in implementing teaching skills are on the skilled criteria with an average of 76.42745. (3) There is an influence of teacher certification on the implementation of teaching skills in primary schools in Sungai Raya sub-district Bengkayang district.
\end{abstract}

Keywords: Teacher Certification, Classroom Teaching Skills 


\begin{abstract}
Abstrak
Guru sebagai pekerjaan professional dengan disahkannya undang-undang No. 14 tahun 2005 tentang guru dan dosen pada tanggal 15 Desember 2005. Menurut Undang-Undang tersebut, guru adalah pendidik professional dengan tugas utama mendidik, mengajar, membimbing, mengarahkan, melatih, menilai, dan mengevaluasi peserta didik pada pendidikan anak usia dini jalur pendidikan formal, pendidikan dasar, dan pendidikan menengah. Penelitian dilakukan untuk mengetahui pengaruh sertifikasi guru dalam mengimplementasikan ketarampilan mengajar di dalam kelas pada sekolah dasar se-kecamatan Sungai Raya. Hal ini dikarenakan adanya keterbatasan alat, media maupun bahan pelajaran di SD yang ada di kecamatan Sungai Raya. Objek penelitian ini adalah guru sekolah dasar yang telah tersertifikasi maupun yang belum tersertifikasi se-kecamatan Sungai Raya kabupaten Bengkayang. Tujuan penelitian ini adalah (1) untuk mengetahui implementasi keterampilan mengajar guru bersertifikasi dikelas, (2) untuk mengetahui implementasi keterampilan mengajar guru tidak bersertifikasi dikelas, (3) untuk mengetahui apakah ada pengaruh sertifikasi guru terhadap implementasi keterampilan mengajar guru di kelas pada sekolah dasar se-kecamatan Sungai Raya kabupaten Bengkayang. Peneliti menggunakan jenis penelitian kuantitatif komparatif. Hasil penelitian yang telah dilakukan dilapangan maka dapat diambil kesimpulan sebagai (1) Guru bersertifikasi dalam mengimplementasikan keterampilan mengajar berada pada kriteria terampil dengan rata-rata 76,79562. (2) Guru yang belum tersertifikasi dalam mengimplementasikan keterampilan mengajar berada pada kriteria terampil dengan rata-rata 76,42745. (3) Terdapat pengaruh sertifikasi guru terhadap implementasi keterampilan mengajar dikelas pada sekolah dasar se-kecamatan Sungai Raya kabupaten Bengkayang.
\end{abstract}

Kata kunci : Sertifikasi Guru, Keterampilan Mengajar Dikelas 


\section{PENDAHULUAN}

Pekerjaan guru sebagai pekerjaan professional yang dilanjutkan dengan disediakannya perangkat-perangkat hukumnya dan kebijakan-kebijakan operasional, upaya peningkatan professional guru semakin serius digalakkan, mulai dari peningkatan kualifikasi guru sampai kepada standardisasi profesionalisme guru melalui program sertifikasi guru (Fasli, 2006).

Sertifikasi guru sebagai salah satu upaya untuk meningkatkan profesionalisme guru telah mendapat perhatian yang luar biasa, namun demikian, tidak semua pihak memahami secara benar konsep ini bahkan kesalahan dalam pemahaman terhadap konsep sertifikasi telah berakibat pada implementasi yang cacat (Payong, 2011).

Prinsip dasar mengajar adalah bagaimana memiliki kesabaran untuk berinovasi dan tidak pernah menyerah dalam menggunakan strategi atau teknik mengajar agar siswa mampu menerima materi dengan baik. Variasi teknik dan gaya mengajar ini memang sangat dibutuhkan, karena masing-masing siswa memiliki kemampuan dan cara belajar yang berbeda. Untuk mendapatkan hasil yang maksimal, guru tidak perlu terpaku dengan satu gaya belajar. Oleh karena itu, guru dituntut untuk mampu memaksimalkan keterampilan mengajarnya (Putra, 2013).

Berdasarkan dengan apa yang terjadi di lapangan, ditemukanlah permasalahan seperti tersendatnya proses pencairan tunjangan yang membuat guru-guru yang telah memiliki sertifikat pendidik mengalami sedikit kekecewaan terhadap program yang dicanangkan pemerintah untuk mencapai tujuan pendidikan nasional yang bermutu dan meningkatkan taraf hidup guru ini. Namun dari berbagai kekurangan di dalam pelaksanaan sertifikasi tersebut, secara sadar ataupun tidak program sertifikasi telah memberikan perubahan bagi pendidikan di Indonesia. Dengan adanya program ini, guru memiliki tanggungan moril terhadap kompetensi yang harus mereka miliki, termasuklah di dalamnya kemampuan atau keterampilan mengajar di dalam kelas.

Kirana Pita Sari (2009) dalam penelitiannya mengemukakan bahwa keberadaan sertifikasi guru sangat direspon positif oleh semua elemen di UPTSP SMP Negeri 1 Jetis Mojokerto termasuk kepala sekolahnya. Diantaranya guru lebih aktif dan kreatif dalam mengajar, Hal ini mengindikasikan bahwa masyarakat sangat antusias dan mempunyai tingkat akseptabilitas yang sangat tinggi khususnya di UPTSP SMP Negeri 1 Jetis Mojokerto dan guru lebih profesional tugasnya sebagai guru. (2) Di UPTSP SMP Negeri 1 Jetis Mojokerto mempunyai 24 guru yang sertifikasi, dan dalam proses belajar mengajarnya telah terjadi peningkatan dalam profesionalisme guru. Di antaranya ; dalam hal inovasi pembelajaran dan guru lebih aktif dalam proses pembelajaran. Begitupun bagi yang belum sertifikasi, mereka antusias untuk selalu belajar kepada guru yang sudah sertifikasi. 
(3) adanya perbedaan antara guru yang belum sertifikasi dengan guru sudah sertifikasi

terhadap profesionalisme guru UPTSP SMP Negeri 1 Jetis Mojokerto, di antaranya guru yang sudah sertifikasi lebih profesional dari pada guru yang belum sertifikasi”.

Nur Budi, Wahyu Ning Tyas (2010) menyatakan bahwa kompetensi guru dalam proses belajar mengajar berpengaruh terhadap prestasi belajar mata pelajaran ekonomi siswa. Hasil penelitian Artana (2011) yang menyatakan bahwa ada pengaruh yang signifikan dan positif antara kompetensi guru terhadap hasil belajar siswa. Eva Myberg \& Monica Rosen (2003) yang menyatakan bahwa pendidikan guru sangat penting untuk pencapaian membaca siswa dan siswi di sekolah berpeforma lebih baik ketika mereka memiliki guru bersertifikat.

\section{METODE PENELITIAN}

Penelitian ini menggunakan metode penelitian kuantitatif, penelitian dilakukan pada sekolah dasar se-kecamatan Sungai Raya. Objek penelitian ini adalah guru sekolah dasar yang telah tersertifikasi maupun yang belum tersertifikasi sekecamatan Sungai Raya kabupaten Bengkayang Kalimantan Barat. Gambar 1. Kerangka Penelitian
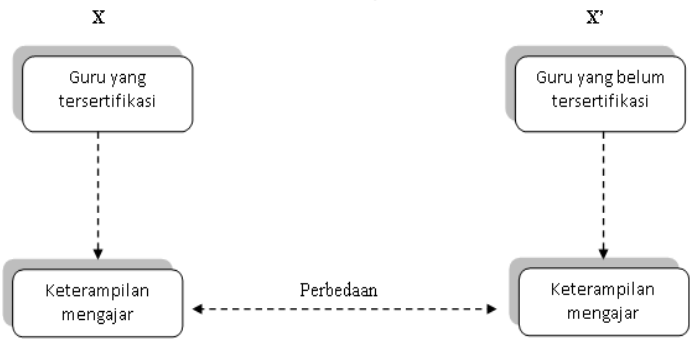

Sumber : Peneliti

Teknik analisis data menggunakan Uji-t merupakan salah satu analisis untuk membandingkan rata-rata dari dua populasi atau lebih (Sugiyono. 2013). Uji-t merupakan statistik parametrik untuk menguji hipotesis deskriptif bila datanya berbentuk interval atau ratio. Dengan kata lain, uji $t$ ini bisa digunakan untuk membandingkan rata-rata sampel yang diuji dengan rata-rata populasi yang sudah ada (Riduwan dan Sunarto, 2009:241).

\section{HASIL DAN PEMBAHASAN PENELITIAN}

Diperoleh responden sebanyak 13 orang guru yang tersertifikasi dan 13 orang guru yang belum tersertifikasi yang tersebar di 3 sekolah yang berada di kecamatan Sungai Raya kabupaten Bengkayang.

Tabel 1. Persentase Keterampilan Mengajar Guru Yang Belum Tersertifikasi

\begin{tabular}{|l|l|c|c|}
\hline Rentang & Klasifikasi & Frekuensi & $\%$ \\
\hline $\begin{array}{l}81- \\
100\end{array}$ & $\begin{array}{l}\text { Sangat } \\
\text { Terampil }\end{array}$ & 4 & $31 \%$ \\
\hline $61-80$ & Terampil & 8 & $61 \%$ \\
\hline $41-60$ & Biasa Saja & 1 & $8 \%$ \\
\hline $21-40$ & $\begin{array}{l}\text { Tidak } \\
\text { Terampil }\end{array}$ & 0 & $0 \%$ \\
\hline $0-20$ & $\begin{array}{l}\text { Sangat Tidak } \\
\text { Terampil }\end{array}$ & 0 & $0 \%$ \\
\hline
\end{tabular}

Sumber : Peneliti

Tabel 2. Persentase Keterampilan Mangajar Guru Tersertifikasi

\begin{tabular}{|l|l|c|c|}
\hline Rentang & Klasifikasi & Frekuensi & $\mathbf{\%}$ \\
\hline $81-100$ & Sangat & 3 & 23 \\
& Terampil & & $\%$ \\
\hline $61-80$ & Terampil & 10 & $\begin{array}{c}77 \\
\%\end{array}$ \\
\hline $41-60$ & Biasa Saja & 0 & $0 \%$ \\
\hline $21-40$ & Tidak & 0 & $0 \%$ \\
& Terampil & & \\
\hline
\end{tabular}




\begin{tabular}{|l|l|c|c|}
\hline $0-20$ & $\begin{array}{l}\text { Sangat Tidak } \\
\text { Terampil }\end{array}$ & 0 & $0 \%$ \\
\hline
\end{tabular}

Sumber : Peneliti

Tabel 3. Hasil Statistik Deskriptif

\begin{tabular}{|l|r|r|}
\hline \multicolumn{1}{|c|}{ Statistics } \\
\hline \multicolumn{1}{|c|}{ Valid } & $\begin{array}{c}\text { Guru Yang } \\
\text { Belum } \\
\text { Tersertifikasi }\end{array}$ & $\begin{array}{c}\text { Guru Yang } \\
\text { Tersertifikasi }\end{array}$ \\
\hline Mean & 13 & 13 \\
Std. Error of Mean & 0 & 0 \\
Median & 76.4274 & 76.7956 \\
Mode & 2.00094 & 1.74934 \\
Std. Deviation & 77.8645 & 77.5015 \\
Variance & $58.70=$ & 79.38 \\
Range & 7.21448 & 6.30735 \\
Minimum & 52.049 & 39.783 \\
Maximum & 25.50 & 21.15 \\
Sum & 58.70 & 67.99 \\
\hline \multicolumn{2}{|c|}{ a. Multiple modes exist. The smallest value is shown } \\
\end{tabular}

Sumber : Peneliti

Berdasarkan data tabel statistik diatas dapat dikatakan bahwa di dalam penelitian yang dilakukan terdapat $N$ atau Jumlah sampel sebanyak 13 orang guru yang belum tersertifikasi dan 13 orang guru yang tersertifikasi. Mean atau rata-rata adalah 76,4274 untuk guru yang belum tersertifikasi dan 76,7956 untuk guru yang tersertifikasi. Std. Error of Mean atau standar kesalahan rata-rata adalah 2,00094 untuk guru yang belum tersertifikasi dan 1,74934 untuk guru yang tersertifikasi. Median atau angka tengah untuk guru yang belum tersertifikasi adalah 77,8645 dan untuk guru yang tersertifikasi adalah 77,5015. Std. Deviation atau ukuran penyimpangan untuk guru yang belum tersertfikasi adalah 7, 21448 dan 6,30735 untuk guru yang tersertifikasi. Range atau selisih dari nilai tertinggi dan nilai terendah untuk guru yang belum tersertifikasi adalah 25,50 dan 21,15 untuk guru yang tersertifikasi. Minimum atau nilai terendah untuk guru yang belum tersertifikasi adalah 58,70 dan 67,99 untuk guru yang tersertifikasi. Maximum atau nilai tertinggi untuk guru yang belum tersertifikasi adalah 84,20 dan 89,14 untuk guru yang tersertifikasi.

Tabel 4. Hasil Uji One Sample t test

One-Sample Test

\begin{tabular}{|c|c|c|c|c|c|c|}
\hline & \multicolumn{6}{|c|}{ Test Value $=0$} \\
\hline & \multirow[b]{2}{*}{$t$} & \multirow[b]{2}{*}{$\mathrm{df}$} & \multirow[b]{2}{*}{ Siq. (2-tailed) } & \multirow[b]{2}{*}{$\begin{array}{c}\text { Mean } \\
\text { Difference }\end{array}$} & \multicolumn{2}{|c|}{$\begin{array}{l}95 \% \text { Confidence Interval of the } \\
\text { Difference }\end{array}$} \\
\hline & & & & & Lower & Upper \\
\hline $\begin{array}{l}\text { Guru Yang Belum } \\
\text { Tersertifikasi }\end{array}$ & 38.196 & 12 & .000 & 76.42745 & 72.0678 & 80.7871 \\
\hline Guru Yang Tersertifikasi & 43.900 & 12 & .000 & 76.79562 & 72.9841 & 80.6071 \\
\hline
\end{tabular}

Sumber : Peneliti

Berdasarkan tabel one-sample test tersebut dapat dilihat bahwa nilai $\mathrm{t}$ hitung untuk guru yang belum tersertifikasi adalah 38,196 dan untuk guru yang tersertifikasi adalah 43,900. Df $=12$, nilai tersebut dapat dicari dengan rumus: $\mathrm{df}=\mathrm{N}-1=13-1=$ 12. Nilai sig.2tailled untuk guru yang belum tersertifikasi adalah 0,000 dan untuk guru yang tersertifikasi adalah 0,000 . Ternyata $\alpha=0,05$ lebih besar dari nilai sig.(sided) atau 0,05 >0,000, maka Ha diterima dan Ho ditolak (Riduwan dan Sunarto, 2009:245). Artinya terdapat pengaruh sertifikasi guru terhadap implementasi keterampilan mengajar dikelas pada sekolah dasar se-kecamatan Sungai Raya kabupaten Bengkayang.

\section{PEMBAHASAN}

Berdasarkan serangkaian proses penelitian yang dilakukan pada guru yang tersertifikasi dan guru yang belum tersertifikasi yang mengangkat judul tentang "Pengaruh Sertifikasi Terhadap Implementasi Keterampilan 
Mengajar Pada Sekolah Dasar SeKecamatan Sungai Raya Kabupaten Benkayang" memberikan beberapa hasil yang sesuai dengan tujuan penelitian guna menjawab masalah yang diangkat oleh peneliti di dalam penelitian ini. Hasil-hasil tersebut dapat dijabarkan sebagai berikut:

1. Guru bersertifikasi memberikan pengaruh yang signifikan terhadap implementasi keterampilan mengajar dikelas pada Sekolah Dasar SeKecamatan Sungai Raya Kabupaten Bengkayang.

2. Terdapat pengaruh guru yang tidak tersertifikasi terhadap implementasi keterampilan mengajar dikelas pada Sekolah Dasar Se-Kecamatan Sungai Raya Kabupaten Bengkayang.

3. Terdapat pengaruh sertifikasi guru terhadap implementasi keterampilan mengajar dikelas pada Sekolah Dasar SeKecamatan Sungai Raya Kabupaten Bengkayang.

Ketiga hasil tersebut sangat menggambarkan kenyataan yang terdapat dilapangan. Selain mendapatkan tiga hasil diatas, peneliti juga menemukan beberapa hal-hal penting yang berkenaan dengan guru, program sertifikasi, dan peserta didik yang terdapat pada sekolah-sekolah tempat penelitian. Hal-hal tersebut dapat dijabarkan sebagai berikut:

\section{Guru}

Guru yang terdapat ditiga sekolah memiliki kekhasan masingmasing tidak terkecuali pada guru yang tidak tersertifikasi dan guru yang tersertifikasi. Secara umum kekhasan tersebut dapat dijabarkan seperti berikut:

\section{Guru yang tidak tersertifikasi.}

Guru yang tidak tersertifikasi yang tersebar ditiga sekolah yang berada di Kecamatan Sungai Raya Kabupaten Bengkayang memiliki semangat mengajar yang luar biasa, mereka mampu mengolah kelas menjadi sangat kondusif walau status mereka adalah guru yang tidak tersertifikasi. Satu hal yang membuat peneliti merasa tersentak saat melakukan wawancara kepada guru yang tidak tersertifikasi adalah guru tersebut mengatakan bahwa "walaupun saya adalah guru yang belum tersertifikasi bukan berarti saya akan memberikan ilmu pengetahuan kepada anak-anak didik saya tidak dengan sungguhsungguh. Saya tahu posisi guru adalah mendidik, mengajar dan mengabdi itulah tugas pokok saya walau saya belum tersertifikasi".

\section{Guru yang tersertifikasi.}

Guru yang tersertifikasi yang tersebar ditiga sekolah yang menjadi tempat penelitian memiliki semangat mengajar yang tinggi walau mereka adalah guru-guru tua tetapi mereka tetap mampu mengolah kelas dengan baik. Terdapat satu keluhan dari guruguru tersebut yaitu dana tunjangan sertifikasi yang tersendat pembayarannya beberapa bulan, namun itu tidak memutuskan semangat kami dalam mengajar ujar salah satu guru tersertifikasi saat diwawancarai. 


\section{Program Sertifikasi}

Program sertifikasi yang dilakukan pemerintah guna meningkatkan mutu pendidikan seharusnya diiringi dengan pemerataan fasilitas pendidikan didaerah. Sebagai contoh, SD Negeri 3 Segedong yang mana tanah dari sekolah tersebut merupakan tanah sengketa dimana pada halaman sekolah ditanami oleh pemilik tanah dengan pohon kelapa, hal itu jelas menganggu pelaksanaan pendidikan disekolah tersebut. halhal seperti ini harusnya bisa diselesaikan oleh para pemegang kepentingan. Selain itu, guna menjadikan program sertifikasi sebagai alat peningkat mutu pendidikan nasional selayaknya dana tunjangan yang merupakan hak bagi guru yang tersertifikasi diberikan sesuai dengan aturan yang ada, karena fakta dilapangan khususnya di sekolah tempat peneliti melakukan penelitian terdapat dana tunjangan sertifikasi yang masih "digantung".

\section{Pemahaman terhadap Peserta Didik}

SD Negeri 01 Sungai Duri guru kurang memberikan evaluasi secara langsung, akan tetapi hal tersebut tertupi karena setiap pembelajaran guru memberikan Pekerjaan Rumah (PR). Namun pada setiap pembelajaran guru sering meminta peserta didik untuk mendemonstrasikan apa yang telah dipelajari hari yang bersangkutan.

SD Negeri 03 Segedong guru mampu memanfaatkan fasilitas belajar yang sangat terbatas sehingga membuat pelajaran lebih bermakna serta guru juga mampu memberikan pemodelan di dalam proses belajar mengajar sehingga siswa mudah memahami materi yang disampaikan.

SD Negeri 08 Sungai Duri guru mampu memanfaatkan fasilitas yang ada sehingga menunjang proses belajar menagajar dengan baik dan didukung dengan kreatifitas guru dalam mengolah kelas menjadi sangat menarik seperti memanfaatkan fasilitas pribadi sebagai bahan ajar. Dan yang tidak kalah pentingnya adalah guru disekolah ini memberikan hukuman kepada siswa yang bandel dengan hukuman yang sangat mendidik.

\section{KESIMPULAN}

Tingkat keterampilan mengajar guru bersertifikasi berada pada status "TERAMPIL" dengan rata-rata sebesar 76,42745.

Tingkat keterampilan mengajar guru yang belum tersertifikasi berada pada status "TERAMPIL" dengan nilai rata-rata sebesar 76,79562.

Terdapat pengaruh sertifikasi guru terhadap implementasi keterampilan mengajar dikelas pada Sekolah Dasar Se-Kecamatan Sungai Raya Kabupaten Bengkayang. Hal tersebut dapat dibuktikan dengan nilai sig. pada kedua kelompok sebesar 0,000 lebih kecil dari nilai $\alpha$ atau dengan kata lain 0,05>0,000.

\section{DAFTAR RUJUKAN}

Payong, Marsel R, 2011. Sertifikasi Profesi Guru. Jakarta: Indeks. 
Putra, Juma de. 2013. Inspirasi Mengajar Ala Harvard University. Jogjakarta: Diva Pres.

Sari, Kirana Pita. 2009. Studi Komparasi Antara Guru Yang Belum Sertifikasi Dengan Guru Sudah Sertifikasi Terhadap Profesionalisme Guru Di Uptsp (Unit Pelaksana Teknis Satuan Pendidikan) Uptsp Smp Negeri 1 Jetis Mojokerto (Online), http://digilib.uinsby.ac.id/7721/ Riduwan, Sunarto. 2009. Pengantar Statistik Untuk Penelitian Pendidikan, Sosial, Ekonomi, Komunikasi, dan Bisnis. Bandung : Alfabeta

Fasli, Jalal. 2006. Sertifikasi Guru Untuk Mewujutkan Pendidikan yang Bermutu. Jakarta: Bumi Aksara.

Inayay Ridaul, Martono Trisno \& Sawiji Hery. 2012. Pengaruh Kompetensi Guru, Motivasi Belajar Siswa, Dan Fasilitas Belajar Terhadap Prestasi Belajar Mata Pelajaran Ekonomi Pada Siswa Kelas XI IPS SMA Negeri 1 Lasem Jawa Tengah Tahun Ajaran 20112012 (Online), http://eprints.uns.ac.id/1961/ 1/1899-4276-1-SM.pdf. Diakses 9 Pebruary 2015.

Jamroni, Ahmad. 2013. Pengaruh Serifikasi Guru Terhadap Mutu Pendidikan (Online), http://katulistiwaonline.blogsp ot.com/2013/09/pengaruhsertifikasi-guru-terhadapmutu.html. Diakses pada 12 Pebruari 2015
Sugiyono. 2013. Metode Penelitian Pendidikan Pendekatan Kuantitatif, Kualitatif dan R\&D. Bandung : $\quad$ Alfabeta. 